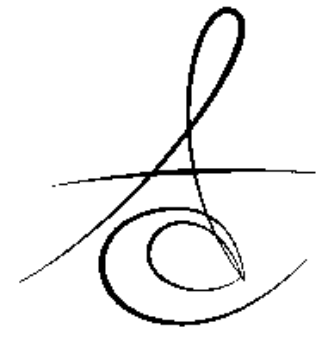

Arş. Gör. Dt. Kübra TÖRENEK*

\section{MONOSTATİK FİBRÖZ DİSPLAZİ: OLGU SUNUMU}

\section{MONOSTATIC FIBROUS DYSPLASIA: A CASE REPORT}

\author{
Prof. Dr. H.Murat AKGÜL*
}

Arş. Gör. Dt. Yasin YAŞA*

Makale Kodu/Article code: 2054

Makale Gönderilme tarihi: 17.01.2015

Kabul Tarihi: 24.04.2015

\section{ÖZET}

Fibröz Displazi (FD), normal kemik metabolizmasında, lokal olarak trabeküler kemiğin fibröz doku ile yer değiştirmesi sonucu görülen benign iskeletsel bir rahatsızlıktır. Radyografik görünümü lezyonun bulunduğu safhaya bağlı olarak değişkenlik göstermekle birlikte, son safhada sergilediği buzlu cam opasifikasyonu spesifiktir. Bu vaka raporunda 40 yaşında bir kadın hasta, mandibular posterior bölgede ağrı ve şişlik şikayeti ile kliniğimize başvurdu. Yapılan klinik ve radyolojik inceleme sonucu hastaya FD teşhisi konuldu.

Anahtar kelimeler: Fibröz Displazi, Monostatik; Mandibula; Dental Volumetrik Tomografi

\section{GİRİŞ}

Fibröz displazi (FD), bir veya daha fazla iskeletsel yapıyı ilgilendiren, normal kemik dokusunun yerini düzensiz trabeküIasyona sahip fibröz bağ dokusunun almasıyla kendini gösteren iyi huylu bir fibro-osseöz lezyon olarak tanımlanır. ${ }^{1-3}$ Hastalığın etiyolojisi tam olarak bilinmemekle birlikte primer olarak genetik faktörler sorumlu tutulmaktadır. ${ }^{2}$

Tek kemik tutulumu görülen tip monostatik; birden fazla kemiği tutan tip poliostatik; genellikle tek taraflı olan kemik lezyonlarının yanı sıra endokrin sistem (puberte prekoks) ve pigmentasyon bozuklukları (etkilenen tarafta café-au-lait lekeleri) görülen durum ise McCune-Albright sendromu olarak adlandırılır. ${ }^{4}$ Poliostatik tip genellikle 10 yaş altı çocuklarda görülürken, monostatik tip diğerine nazaran daha

\section{ABSTRACT}

Fibrous Dysplasia (FD) is a benign skeletal disorder which results from a localized change in normal bone metabolism that results in the replacement of all the components of cancellous bone by fibrous tissue. Although radiographic appearance vary depending on stage of maturation lesion, ground glass opacification is characteristic in mature lesion. In this case report, a 40-year-old woman referred to our clinic with complaints of pain and swelling in mandibular posterior region. It was diagnosed as FD after clinical and radiological examination. After operation, during one year follow-up, there was no signs of recurrence.

Key words: Fibrous dysplasia, Monostatic; Mandible; Dental Volumetrik Tomography

ileri yaşlarda görülür. FD’nin \%70 oranında görülen monostatik formu en sık femurun proksimal ucunu, tibia ve kafa-yüz kemiklerini tutar. ${ }^{1,2}$ FD baş boyun bölgesinde ise genellikle \% 85 oranında çenelerde ortaya çıkar. Maksillada mandibulaya oranla 2 kat daha fazla olmak üzere, sıklıkla posterior bölgede tutulum görülür ve genellikle tek taraflı izlenir. ${ }^{1}$

Hastalık klinik olarak tutulan bölgede ağrı, fraktür ve kemiklerde ekspansiyonla kendini gösterir. FD olgularının çoğunluğu radyografik incelemeler sırasında tesadüfen saptanmaktadır ve lezyonun maturasyonuna göre farklı görünüm verebilmektedir. Geleneksel radyografilerde özellikle mandibulada iğsi genişlemeler ve maksillada ise antral bölgede genişlemeler görülür. Başlangıç aşamasındaki lezyonlar radyolüsent bir görünüm verirken, lezyonda zamanla artan radyoopak kemik formu izlenir. Matür lezyonlar ise tipik buzlu cam veya portakal kabuğu görünümündedir. ${ }^{1,3,5,6}$

\footnotetext{
*Atatürk Üniversitesi Diş Hekimliği Fakültesi Ağız, Diş ve Çene Radyolojisi A.D.
} 
FD teşhisi, radyografik ve histopatolojik tetkiklerle konulur. ${ }^{2,3,5,7,8}$ Birçok olguda radyografik ve klinik bulgular hekimin biyopsiye gerek duymadan teşhis koyması için yeterli olmakla birlikte, kesin tanı ve tedavi planlaması için lezyonun sınırlarının saptanması amacıyla bilgisayarlı tomografi (BT) tercih edilmektedir. . $^{3,5,9}$

$\mathrm{Bu}$ olguda, kliniğimize gelen bir FD vakasının klinik ve radyografik sunumu amaçlandı.

\section{OLGU SUNUMU}

40 yaşında bayan hasta sağ mandibular posterior bölgede ağrı ve şişlik şikayeti ile Atatürk Üniversitesi Ağız, Diş ve Çene Radyolojisi kliniğine başvurdu. Anamnezinde 8 yıl önce o bölgeden diş çektirdiğini ve şikayetlerinin bundan sonra oluştuğunu ifade etmekteydi. Herhangi bir sistemik problemi olmayan hastanın panoramik ve DVT incelemesinde mandibular sağ 2. premolar dişin apeksi hizasında radyolüsent bir saha, yer yer kalsifiye odaklar ve periferinde de buzlu cam görünümü izlendi (Resim 1 ve 2). Mandibular molar bölgede de, bukkal ve lingual ekspansiyona sebep olan, buzlu cam opasifikasyonu gösteren lezyon tespit edildi. Lezyon mandibular kanal ile ilişkili olup, kanal bukkal kortikal kemiğe yakın olarak lezyon içerisinde seyretmekteydi (Resim 3). Mandibular sağ 1 . ve 2. premolar dişlerin periapikalinde, içerisinde kalsifiye odaklar içeren kistik, litik alanlar izlenmekteydi (Resim 4).

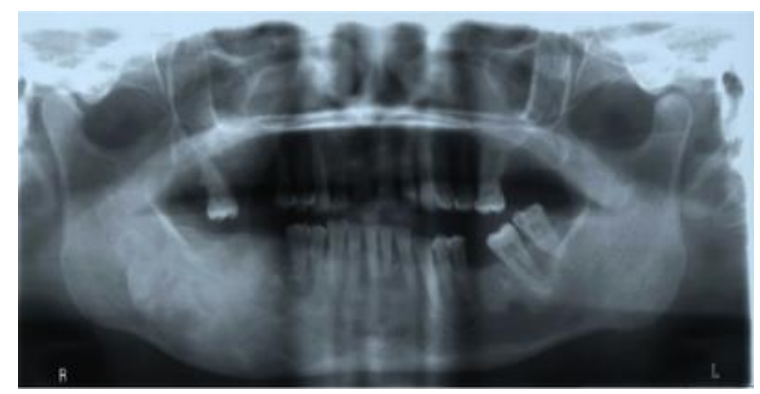

Resim 1. Hastanın operasyon öncesi panoramik radyograf görüntüsü.
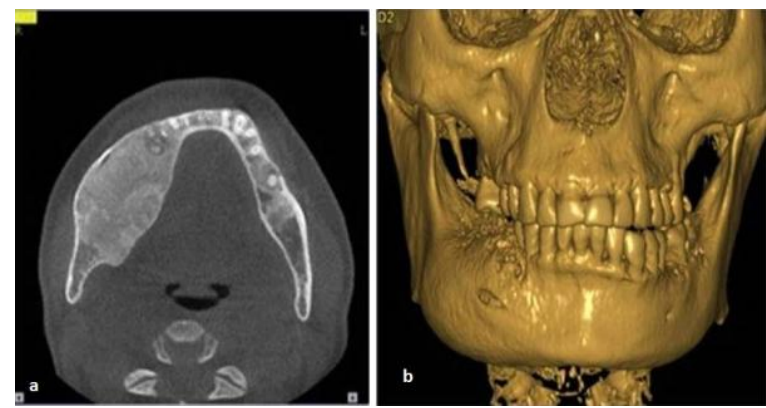

Resim 2. DVT ile oluşturulan a. aksiyal kesit (bukkal ve lingual korteksin ekspansiyonu izleniyor) b. 3 boyutlu görüntüsü.

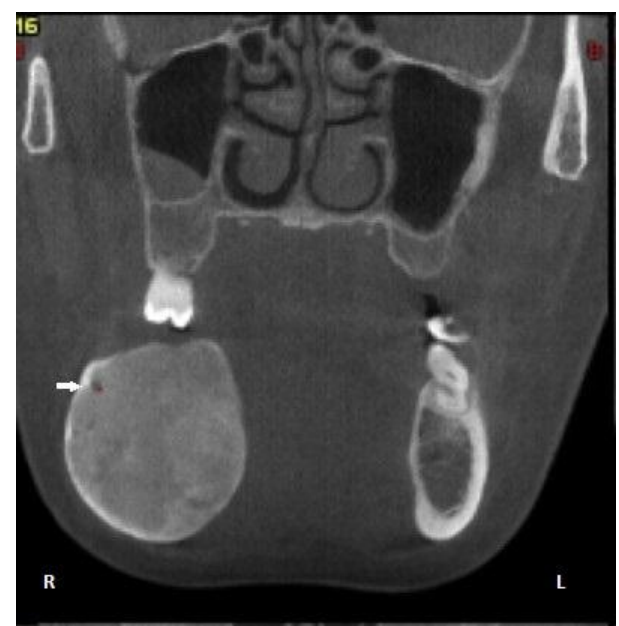

Resim 3. Lezyondan etkilenen mandibular kanalın bukkosuperior yöndeki yer değişimi (DVT-Koronal kesit).

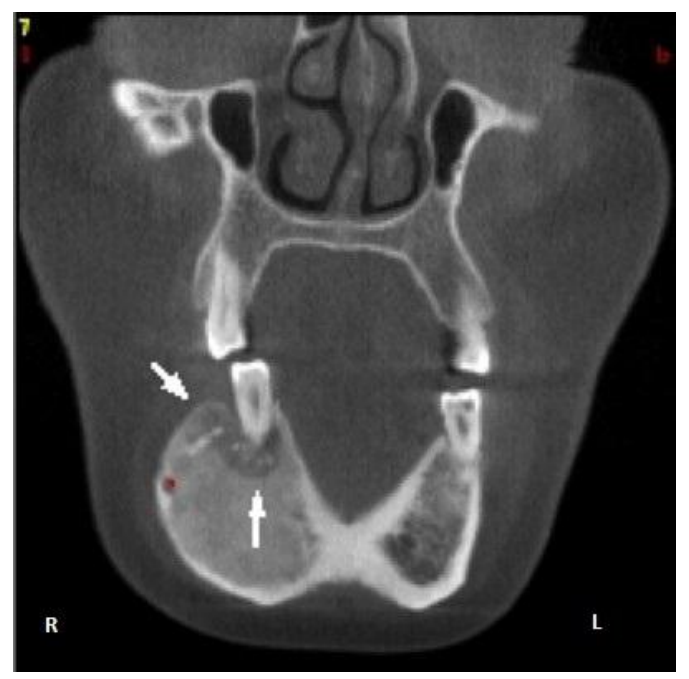

Resim 4. Mandibular premolar apeks bölgesinde izlenen kalsifiye odaklar. (DVT-koronal kesit). 


\section{TARTIŞMA}

$F D$, normal kemiğin fibröz bağ dokusu ile yer değiştirmesi sonucu ortaya çıkan gelişimsel anomalidir. ${ }^{1,5,6,10}$ Bir ya da daha fazla kemiğe yerleşebilir. Monostatik vakalarda tutulan bölge $\% 10$ oranında kraniyofasiyal yapılardır. Vakaların \%50 sinde maksilla, mandibuladan daha fazla tutulur. ${ }^{5,9,11}$ Olgumuzda maksillofasiyal bölgede yapılan konvansiyonel radyografi ve DVT incelemelerinde lezyonun sadece mandibulayı tuttuğu, diğer kemiklerin etkilenmediği belirlendi. Vücudun herhangi bir yerinde ciltte pigmentasyon değişikliği de söz konusu olmadığından olgumuz monostatik FD ile uyumlu görüldü.

FD genellikle puberte öncesi çocuklarda görülmesine karşın, puberte sonrası ileri yaş gruplarında da rapor edilmiştir. ${ }^{5,9-11}$ Poliostatik tip genellikle 10 yaş altı çocuklarda görülürken, monostatik tip poliostatik tipe nazaran daha ileri yaş gruplarında görülmektedir. Lezyon puberte öncesi aktif formda görülürken, daha sonra statik bir durum alabilir. Özellikle poliostatik tipte olmak üzere hormonal değişiklikler ve cerrahi müdahale, durağan lezyonu aktif hale getirip anormal büyümesini tetikleyebilir. ${ }^{12}$ Bizim vakamızda hastamı genel durumun aksine daha ileri yaştadır ve anamnezinde ilgili bölgeye uygulanan cerrahi müdahaleden söz etmektedir.

Monostotik tip FD'de lezyonlar sıklıkla unilateraldir. Ancak maksillofasiyal bölgenin çok nadir görülen geniş lezyonlarında bilateral tutulum da olabilir. ${ }^{1,12,13}$ Bizim olgumuzda lezyon mandibulada unilateral olarak izlenmiştir.

FD'de teşhis, radyolojik görüntüleme yöntemleriyle konulabilir. ${ }^{1,2,6,10}$ Lezyon radyografide radyoopak, radyolüsent veya ikisinin karışımı (mikst) şeklinde görülebilir. Erken safhada genellikle lezyon radyolüsenttir. İlerleyen safhalarda trabeküler kemiğin incelmesi, kısalması, düzensiz sınırlanması sonucu artan opasite ile birlikte mikst veya buzlu cam dansitesinde, kemikte ekspansiyon yapan bir görüntü verebilir. FD; santral dev hücreli granülom, ossifying fibrom, ameloblastik fibrom ve ameloblastik fibroodontom ve osteosarkom gibi benzer radyografik görünüm sergileyen lezyonlardan ayırt edilmelidir. ${ }^{6,11-14}$ Özellikle malign bir patoloji olan osteosarkom, radyolojik ve histolojik olarak $\mathrm{FD}^{\prime}$ nin başlangıç safhası ile benzerlik gösterdiğinden ayırıı tanıda önem taşımaktadır. Osteosarkom güneş ışığı ve codman üçgeni gibi periost reaksiyonları ile malign bir tablo sergiler. FD ise internal yapıda genişleme ve dış kortekste incelme ile osteosarkomdan ayrilır. ${ }^{1}$ Çoğu FD vakasında klinik görünüm ve radyolojik tetkikler biyopsiye gerek duyulmaksızın tanı için yeterli olmaKtadır. Olgumuzdaki buzlu cam görünümü de FD tanısı için karakteristik olduğundan biyopsiye gerek duyulmadı. Ayrıca vakamızın radyografik görüntüsü, FD'nin ileri dönem radyografik bulgularından olan "keskin marjinal sınırları olmayan radyoopasiteler" ile de uyumludur.

FD'de lezyonlar genellikle asemptomatik olmasına rağmen, ilk gelişim aşamasında hastalar yüzlerindeki şişlik ve asimetriden bahsederler. Daha önce MacDonald-Jankowski ${ }^{11}$ tarafından yapılan bir sistematik derlemede, en yaygın görülen şikayetlerin $\% 94$ oranında şişlik ve $\% 15$ oranında ağrı olduğu ifade edilmiştir. Ancak lezyon, kanallar ve foraminalar gibi önemli anatomik oluşumları işgal ederse, ağrı ve parestezi gibi rahatsızıkların ortaya çıkması ile semptomatik bir hal alır. ${ }^{3,9,12}$ Mandibuladaki bu tarz FD lezyonlarında mandibular kanal, inferior veya superior yönde yer değiştirebilir. Petrikwoski ve ark. ${ }^{8}$ mandibular kanalın superior yöndeki hareketinin FD için patognomik olduğunu bildirmişlerdir. Olgumuzun DVT görüntülemesinde de mandibular kanalın bukkale ve superiora yer değiştirmiş olduğu izlendi. Bu özellik, mandibuladaki FD' nin diğer fibro-osseöz lezyonlardan ayrımı için önemli bir bulgudur. Periodontal ligament kaynaklı diğer fibro-osseöz lezyonlar ise, mandibular kanalın üzerinde ve dental yapıların yakınında gelişirler. ${ }^{8,12,13}$

Birçok vakada iyi yapılmış bir klinik ve radyolojik muayene biyopsi almadan FD teşhisi için yeterli olmaktadır. ${ }^{1,7,9,11} \mathrm{FD}$ olgularında malignite çok fazla rapor edilmemiştir. Bu hastalarda malign dönüşüm riski nedeniyle radyoterapi kontrendikedir. Asimetri, ağrı gibi şikayetlerin, ciddi fonksiyonel bozuklukların olduğu semptomatik vakalarda veya malign transformasyon görüldüğünde cerrahi tedaviye başvurulabilir, asemptomatik hastalar ise genellikle takip edilir. ${ }^{3,5,9,15,16}$ Bizim vakamızda da biyopsiye gerek duyulmadan FD teşhisi konuldu. Bazı ailevi ve sosyal nedenlerden dolayı başka bir merkezde tedavi gören hastanın hekimiyle koordinasyon sağlanamadığından operasyon sonrası bulgularına ulaşılamadı.

Sonuç olarak, DVT günümüzde birçok hastalık ve çene lezyonu için tanısal değer taşıdığı gibi bizim 
FD olgumuzda da gerek teşhis gerekse tedavi planlaması konusunda yol gösterici olarak kullanılmıştır. Konvansiyonel radyografiler ile karşılaştııııı̆ı̆ında daha net ve kapsamlı bilgi sunması, medikal bilgisayarlı tomografilere oranla daha düşük radyasyon dozu ile görüntü sağlaması faktörleri de göz önünde bulundurulduğunda, DVT'ler bu alanda vazgeçilmez bir yöntem olmaya devam edecektir.

\section{KAYNAKLAR}

1. Goaz PW, White SC. Oral radiology: principles and interpretation. 3rd ed. St. Louis: Mosby; 1994. p.735.

2. Collins MT. Spectrum and natural history of fibrous dysplasia of bone. J Bone Miner Res 2006;21 (Suppl 2):99-104.

3. Langland $\mathrm{OE}$, Langlais RP. Early pioneers of oral and maxillofacial radiology. Oral Surg Oral Med Oral Pathol Oral Radiol Endod 1995;80:496-511.

4. Shenker $A$, Weinstein LS, Moran A, Pescovitz $\mathrm{OH}$, Charest $\mathrm{NJ}$, Boney CM, Van Wyk JJ, Merino MJ, Feuillan PP, Spiegel AM. Severe endocrine and nonendocrine manifestations of the McCuneAlbright syndrome associated with activating mutations of stimulatory G protein GS. J Pediatr 1993;123:509-18.

5. De Melo WM, Sonoda CK, Hochuli-Vieira E. Monostotic Fibrous Dysplasia of the Mandible. J Craniofac Surg 2012;23:452-4.

6. Feller L, Wood NH, Khammissa RA, Lemmer J, Raubenheimer EJ. The nature of fibrous dysplasia. Head Face Med 2009;5:22.

7. Atalı O, Namdar Pekiner F, Varol A, Dumlu A, Özbayrak S, Alatlı C. Fibröz displazili bir bayan hastanın radyolojik ve histolojik değerlendirilmesi. Marmara Üniversitesi Sağlık Bilimleri Enstitüsü Dergisi 2012;2:193-7.

8. Petrikowski CG, Pharoah MJ, Lee L, Grace MG. Radiographic differentiation of osteogenic sarcoma, osteomyelitis, and fibrous dysplasia of the jaws. Oral Surg Oral Med Oral Pathol Oral Radiol Endod 1995;80:744-50.

9. Selçuk Ü, Muğlalı M, Çelenk P, Canger M, Günhan Ö. Monostatik fibröz displazi : Olgu sunumu. Journal of Experimental and Clinical Medicine 2013;30:91-5.
10. Atalar M, Ozum U. Monostotic fibrous dysplasia of the clivus: imaging findings. Turkish Neurosurgery 2010;20:77-81.

11. MacDonald-Jankowski D, Yeung R, Li TK, Lee KM. Computed tomography of fibrous dysplasia. Dentomaxillofac Radiol 2004;33:114-8.

12. Singer SR, Mupparapu M, Rinaggio J. Clinical and radiographic features of chronic monostotic fibrous dysplasia of the mandible. J Can Dent Assoc 2004;70:548-52.

13. Slootweg PJ. Maxillofacial fibro-osseous lesions: classification and differential diagnosis. Semin Diagn Pathol 1996;13:104-12.

14. O'Connell KJ. Bony enlargement of the left maxilla. J Am Dent Assoc 1981;102:340-2.

15. Acıbucu F, Kılıçlı F, Dökmetaş HS. Kemiğin fibröz displazisi ve McCune-Albright sendromu: bir olgu sunumu ve literatürün gözden geçirilmesi. Cumhuriyet Medical Journal (CMJ) 2011;33:93-6.

16. Çakur B, Durna D, Bilge OM, Yıldırım E. Fibröz displazi: bir olgu sunumu. Atatürk Üniv Diş Hek FakK Derg 2014; 24:1-3

\author{
Yazışma Adresi \\ Arş.Gör.Dt.Kübra TÖRENEK \\ Atatürk Üniversitesi Diş Hekimliği Fakültesi \\ Ağız,Diş ve Çene Radyolojisi ABD \\ 25240 Erzurum / TÜRKIYYE \\ Tel: +90 4422311753 \\ Faxı: +90 4422360945 \\ E-mail:ktorenek@gmail.com
}

